\title{
Social Insurance for farmers in Austria - from its inception to the SVS
}

\author{
Sara Plimon-Rohm
}

\begin{abstract}
After existing for 46 years, the Austrian Farmers Insurance Institution (in German: Sozialversicherungsanstalt der Bauern - SVB) was merged into the Social Insurance Institution for the Self-Employed on 31 December 2019 and ceased to exist. Social insurance protection for farmers in Austria goes back further than 1974 and did not end with this reform. Over the years, the SVB has continually widened and improved its range of services, which became specialised for people working in agriculture and forestry. The following article will pinpoint the most important stages in the development of social insurance for farmers into what it is today, explain contributions and benefits, and present the available health programmes and initiatives as well as the Sozialversicherung der Selbständigen itself (the SVS), with a focus on agriculture. Social insurance in Austria is obligatory, meaning that as soon as a person takes up an occupation - either as an employee or self-employed - they gain social security coverage. As work on farms cannot be compared easily to other fields of work, the SVS offers different programmes and initiatives tailored to the need of people active in the agricultural sector or forestry.
\end{abstract}

Keywords: agriculture, insurance protection for farmers, social insurance, SVB, SVS.

Sara Plimon-Rohm, LL.M., Sozialversicherung der Selbständigen (SVS), Austria. 


\section{Introduction and historical background}

The purpose of this article is to describe the social insurance system for farmers in Austria and to present the different initiatives and benefits organised by the social insurance institution for farmers. When composing this article, the available publications on farmers' insurance in Austria and the relevant legal provisions were reviewed. The primary sources were the intranet-based federal legal data bank ${ }^{1}$, the MANZ online database ${ }^{2}$ and information published by the SVB and SVS. Both historical and recent articles have been chosen as sources, and the most important papers have been compiled and compared to current social insurance law.

The Austrian social system is built on three different pillars: social insurance, which includes unemployment insurance, social services, and social benefits as well as the needs-based minimum benefits ${ }^{3}$. Social insurance in Austria is compulsory and comprises health, pension, and accident insurance. Social insurance law determines the allocation of insured individuals to the competent social insurance institution, depending on their profession and manner in which they exercise said profession $^{4}$. Due to the importance of the division between working for an employer and being self-employed and the associated decision on where a person is insured, the Austrian government introduced a special law that makes it possible to assess in advance which social insurance act a person is subject to, and thereby which social insurance institution they are to be allocated to ${ }^{5}$. The federal state's role is limited to monitoring the social insurance institutions and controlling their effectiveness, compliance with statutory requirements and finances ${ }^{6}$.

The Farmers' Social Insurance Act (in German: Bauern-SozialversicherungsgesetzBSVG) regulates health, accident and pension insurance for all self-employed persons active in agriculture and forestry in Austria as well as the members of their families working with them and those classified as pensioners under said $\operatorname{law}^{7}$. Furthermore, the statute, the Krankenordnung (a regulation enacted by the institution's self-governing bodies determining the rights and obligations of the insured persons) and internal

1. The intranet-based federal legal data bank, https://www.ris.bka.gv.at/.

2. The MANZ online database, https://rdb.manz.at/home.

3. See Die Sozialversicherung bietet Schutz für 8,8 Millionen Menschen, "Soziale Sicherheit" 2019, p. 290.

4. $\$ 10$ Sect. 1 Allgemeines Sozialversicherungsgesetz (ASVG). J. Souhrada, Pflichtversicherung oder Versicherungspflicht in der Krankenversicherung, "Soziale Sicherheit" 2001, p. 133.

5. H. Lidauer, Neuregelung der Zuordnung von Sozialversicherten nach dem SV-ZG, "Journal für Arbeitsrecht und Sozialrecht" 2018, p. 222.

6. H. Aubauer, M. Rosenmayr-Khoshideh, Sozialversicherungs-Organisationsreform und Grenzen der Staatsaufsicht, "Zeitschrift für Arbeitsrecht und Sozialrecht" 2019, Nr. 11, p. $61 \mathrm{f}$.

7. $\$ 1$ Bauern-Sozialversicherungsgesetz (BSVG). 
guidelines from administrative bodies are relevant internal sources of law operating the insurance. After major structural reform of the Austrian social insurance institutions, Austria's Social Insurance Institution (in German: Sozialversicherungsanstalt der Bauern) became solely responsible for farmers and their relatives. The Sozialversicherungsanstalt der Bauern (SVB) ceased to exist and was merged into the newly established SVS, a social insurance institution responsible for all self-employed individuals in Austria, according to the Social Insurance Organisation Act ${ }^{8}$.

In 1929, the Act on Insurance for Agricultural Workers (in German: Landarbeiterversicherungsgesetz) came into force and established accident insurance for farmers and their family members in Vienna, Lower Austria, and Burgenland ${ }^{9}$. Ten years later, said insurance was expanded to all farmers and their family members, regardless of which federal state they operated their farm or lived in. The Social Insurance Institution for Agriculture and Forestry launched accident insurance for farmers in $1948^{10}$. The General Social Insurance Act (in German: Allgemeines Sozialversicherungsgesetz - ASVG), came into force in 1956 and contains various provisions concerning farmers, the foremost among which introduced the system of accident insurance for farmers while replacing the Landarbeiterversicherungsgeset $z^{11}$.

The Agricultural Supplementary Pension Insurance Act introduced basic flat-rate benefits as subsidies for retired agricultural workers and their family members in $1958^{12}$. These benefits were not established as future pension benefits and should have ensured the livelihood of retired farmers in addition to the share of property these farmers received on their retirement due to special rules connected with the transfer of farming businesses to the next generation of farmers (in German: Ausgedinge) ${ }^{13}$.

8. Sozialversicherungs-Organisationsgesetz - SV-OG (NR: GP XXVI RV 329 AB 413 S. 57. BR: 10079 AB 10082, p. 888.

9. J. Rudda, Die neue Unfallversicherung der Bauern im Lichte der Österreichischen Sozialpolitik, "Soziale Sicherheit" 1999, p. 96; Landarbeiterversicherungsgesetz vom 18. Juli 1928, BGBl. Nr. 235, in der Fassung der 1. Novelle vom 18. Juli 1929, BGBl, Issue 253.

10. E. Bruckmüller, R. Sandgruber, H. Stekl, Soziale Sicherheit im Nachziehverfahren - Die Einbeziehung der Bauern, Landarbeiter, Gewerbetreibenden und Hausgehilfen in das System der österreichischen Sozialversicherung, Salzburg 1978, p. 96.

11. Bundesgesetz vom 9. September 1955 über die Allgemeine Sozialversicherung (Allgemeines Sozialversicherungsgesetz - ASVG.) StF: BGBl. Nr. 189/1955 idF BGBl. Nr. 18/1956 (DFB) (NR: GP VII RV 599 AB 613 S. 79. BR: S. 108.).

12. Bundesgesetz vom 18. Dezember 1957 über die Landwirtschaftlichen Zuschussrenten (Landwirtschaftliches Zuschussrentengesetz - LZVG), BGBl. Nr. 293.

13. The Ausgedinge is a set of rights that can include the right of residence, the right to care, periodical payments and contributions in kind, agreed upon between a party handing over property and the recipient. It was intended as a retirement option in the agricultural sector and bears in mind that farms are not only the work-place but also home for farmers and their families. "Old farmers" would hand over their farming business and all rights and obligations connected thereto to one of their children. They would keep living on the farm in the so-called "elders parts" of the farmhouse and receive payments, as provided for in the Ausgedinge. H. Kranewitter, Ausgedinge, "Österreichische Zeitschrift für Liegenschaftsbewertung" 2009, Nr. 36, p. 85. 
Parallel to this act, the Agricultural Supplementary Pension Insurance Institution was founded ${ }^{14}$. Over twenty years later, supplementary benefits were converted into pensions according to the Farmers' Pension Insurance Act (in German: Bauern-Pensionsversicherungsgeset $z)^{15}$.

As the new Farmers' Health Insurance Act came into effect in 1965/1966, National Health Insurance Funds were established in every federal state. Before 1965, farmers had the option to choose a voluntary insurance, according to the ASVG, in order to receive monetary or other benefits from the Agricultural National Health Insurance Funds ${ }^{16}$. Under the guiding principle of "all services under one roof", the Social Insurance Institution for full-time and part-time farmers (in German: Sozialversicherungsanstalt der Bauern) was founded in $1974^{17}$. Although this did not entail any big changes regarding the benefits available, in 1979 the Farmers' Social Insurance Act came into force. It included all regulations concerning health and pension insurance and most of the regulations concerning accident insurance for farmers ${ }^{18}$. Important changes and amendments for farmers and their families after the founding of the SVB include the introduction of pensions for farmers' wives, a maternity allowance for female farmers in 1998, paternal leave in 2002, and a general pension reform in $2005^{19}$.

The Austrian government enacted a major reform of the social insurance institutions in $2019^{20}$. Accordingly, the SVB and the Social Insurance Institution for the Self-Employed were merged into the SVS ${ }^{21}$. As the SVS is the legal successor of both former institutions, it assumed all of the SVB's rights and obligations; the SVS also performs similar functions and services as the SVB for its customers ${ }^{22}$. The following remarks will be focused on the offers tailored for farmers, which were developed in the SVB during the past decades.

14. E. Bruckmüller, R. Sandgruber, H. Stekl, Soziale Sicherheit im Nachziehverfahren - Die Einbeziehung der Bauern, Landarbeiter, Gewerbetreibenden und Hausgehilfen in das System der österreichischen Sozialversicherung, Salzburg 1978, p. 100.

15. First only into so-called "Übergangspensionen", transitional pensions, then the Bauern-Pensionsversicherungsgesetz entered into force in 1971, introducing retirement schemes for farmers.

16. P. Flora (ed.), Growth to Limits - The Western European Welfare States Since World War II., Vol. 4, European University Institute, Berlin 1987, p. 541.

17. G. Schwarz, 40 Jahre SVA der Bauern, "Soziale Sicherheit" 2015, p. 31.

18. Some regulations regarding accident insurance remained codified in the Allgemeines Sozialversicherungsgesetz (ASVG).

19. SVB, Die bäuerliche Sozialversicherung im Überblick, Vienna 2019, p. 21f. See G. Steiner, G. Siegl, Ja, jetzt geht es mir gut... Entwicklung der bäuerlichen Sozialversicherung in Österreich, 2010.

20. H. Aubauer, M. Rosenmayr-Khoshideh, Sozialversicherungs-Organisationsreform und Grenzen der Staatsaufsicht, "Zeitschrift für Arbeitsrecht und Sozialrecht" 2019, Nr. 11, p. 52.

21. Sozialversicherungs-Organisationsgesetz - SV-OG (NR: GP XXVI RV 329 AB 413 S. 57. BR: 10079 AB 10082, p. 888.

22. $\$ \$ 47,51$ Selbständigen-Sozialversicherungsgesetz (SVSG). 


\section{Who is insured under the Farmers' Social Insurance Act?}

As mentioned, the SVS is responsible for insuring all self-employed persons working in Austria, including farmers. All persons insured under the Farmers' Social Insurance Act that were previously insured with the SVB are now automatically insured with the $\mathrm{SVS}^{23}$. If a person has multiple occupations, they are insured individually for each occupation. Only insured occupations covered under the same Insurance Act are insured conjointly with a higher contribution basis. Self-employed farmers working in agriculture or forestry within the territory of Austria and their full-time working family members are insured under the Farmers' Social Insurance Act ${ }^{24}$. Obligatory insurance is dependent on certain age limits and a taxation value (in German: Einheitswert) ${ }^{25}$ determined by the law. Self-employed farmers are those who run an agricultural holding in their own name, for their own account and at their own risk. In addition to the farmer, all shareholders of a general partnership or a limited partnership (OGs and KGs) are covered under obligatory insurance in accordance with the BSVG if the partnership runs a farm. Furthermore, any child, stepchild, grandchild, spouse, parent, stepparent or grandparent is insured under the health and pension insurance if they are working full-time at the farm. Health and pension insurance under the BSVG begin if the taxation value of the farm reaches 1,500 euros or the farm is the only source of income ${ }^{26}$. This means that a farming business that has a fiscal value of 1,500 euros or above falls under the mandatory social health and pension insurance. Accident insurance under the BSVG is broader as it also includes farmers' siblings, even if they only occasionally work at the farm, and starts at a taxation value of 150 Euro which is much less that the value for the pension and health insurance due to the importance of the accident insurance and possible dangers connected to work in the agricultural sector ${ }^{27}$.

Coverage under health and accident insurance starts on the day the farmer or their relative begins work at the farm. Concurrently, the insurance ends on the day when work on the farm is ceased. For pension insurance, the beginning and end is

23. $\$ 3$ SVSG. K Nakhai, S. Bunda, SVS: Gesamtvertrag mit der Ärztekammer besiegelt, https://www.ots. at/presseaussendung/OTS_20191119_OTS0107/svs-gesamtvertrag-mit-der-aerztekammer-besiegelt, access 30.03.2020.

24. $\$ 1$ Bauern-Sozialversicherungsgesetz (BSVG).

25. The Einheitswert is a taxation or fiscal value that is an assessed value set by the tax authorities for tax purposes classifying the assumed productivity of agricultural land or agricultural enterprise and depends on the type of the agricultural area/land. This fiscal value is converted to the monthly contribution base based on a pre-defined formula by law, SVS, Beitragsgrundlage für Bauern, https://www.svs.at/cdscontent/?contentid=10007.816645\&portal=svsportal, access 09.04.2021.

26. $\$ 2$ Bauern-Sozialversicherungsgesetz (BSVG).

27. $\$ 3$ Bauern-Sozialversicherungsgesetz (BSVG). 
always tied to the first day of the given month ${ }^{28}$. In 2018, 130,427 active and 144,388 retired farmers and their relatives were covered under health insurance ${ }^{29}, 257,836$ agricultural holdings were covered under accident insurance ${ }^{30}$, and 135,217 persons were covered under farmers' pension insurance ${ }^{31}$.

\section{Contributions}

Whereas the contribution employed people are required to pay into the public insurance scheme amounts to a percentage of their income, farmers' contributions are calculated differently. One option available is to calculate farms' and agricultural properties' taxation value, which is determined by the tax authorities and binds the social insurance institution. A percentage of the taxation value equals the insurance sum and the contribution base for the farmer determining how high the contributions are. Most agricultural secondary activities, such as agrotourism, are subject to contributions as well. The only exceptions are those secondary activities that are already considered when calculating the taxation value. The law determines if a secondary activity is calculated to the taxation value or if the expected benefits are already taken into consideration when determining the taxation value (e.g. the taxation value and classified productivity for wine-growing areas are comparably higher than other farmland, this is then taken into consideration so that the benefits of traditional wine tavern are not added to the calculation value when determining the contribution base as a secondary activity additional to producing wine). Farmers may also operate agricultural side-line activities, like working on and processing of natural products, traditional wine taverns (in German: Buschenschank) and agrotourism activities. Different activities are subject to different taxation rules and social security contributions. Agrotourism includes renting private rooms and apartments and offering food to tourists at the farm ${ }^{32}$.

The second option for calculating a farmer's social insurance contributions is by using their actual income from the agriculture and forestry activities, according to the income tax assessment notice issued by the tax authority, as the contribution base and not the assumed productivity depending on the classification of the

28. \$6f. Bauern-Sozialversicherungsgesetz (BSVG).

29. SVB, Jahresbericht 2018, Vienna 2019, p. 98.

30. Ibidem, p. 112.

31. Ibidem, p. 122.

32. SVS, Bäuerliche Nebentätigkeiten I, Vienna, January 2020, https://www.svs.at/cdscontent/load? contentid $=10008.732003 \&$ version $=1580914454$, access 24.09 .2020 , p. 20 . 
agricultural area. This method of calculating the contribution base is only utilised/ applied upon request by the farmer. The farmer pays all contributions for themselves and their family members to the SVS. Most of contributions are due quarterly in arrears and have to be paid within one month of receiving the payment notice ${ }^{33}$. As the Austrian farmers' insurance law is based on the principle of standard values of agricultural properties (as the taxation value just expresses the assumed productivity) and its minimum contribution basis and minimum contributions are both legally determined, minimum contributions have to be paid even if the farm did not make any profit. Farmers may apply to the SVS for an extension of the payment deadline for contributions or for the option to pay in instalments.

If more than one farmer operates a farm, they are jointly liable for social insurance contributions. Contributions for agricultural secondary activities are due once a year and must be paid within one month of receiving the payment notice. Since social insurance is obligatory, the insurance coverage does not end when contributions are not paid. The farm operator, within the meaning of the BSVG, is the person running the farm in their own name, at their own risk and for their own account. Farms may be operated by individuals, married couples or partnerships ${ }^{34}$. Health and pension insurance contributions must be paid for the farm operator or operators and every working relative.

In order to obtain health insurance for other family members, the farmer must pay an additional contribution of $3.4 \%$ of the contribution base $\mathrm{e}^{35}$. Accident insurance contributions are payable per farm. Since 2009, farmers do not have to pay additional contributions for their children aged under 18 if they are not working on the farm. Farmers are also not obliged to pay contributions for inpatient hospital stays and treatments for their minor children. For most others, the patient must pay a contribution to the costs of an inpatient treatment or stay ${ }^{36}$.

When it comes to contributions, another main difference to employed persons is that due to the lack of an employer, contributions have to be paid in full by the insured person, whereas contributions of people insured by the ASVG is almost equally divided between the employer and the employee (i.e. the insured person). Contribution rates vary depending on which type of insurance they pertain to: for health insurance $-6.8 \%$, for pension insurance $-17 \%$, and for accident insurance $-1.9 \%$

\footnotetext{
33. $\$ 33$ Bauern-Sozialversicherungsgesetz (BSVG).

34. $\$ \$ 2$ Sect. 1 No. 1 and No 1a, 2a Sect. 1 Bauern-Sozialversicherungsgesetz (BSVG).

35. $₫ 24 \mathrm{~b}$ Bauern-Sozialversicherungsgesetz (BSVG).

36. J. Kandlhofer, Eine Ursachenanalyse der Finanzierungsprobleme der sozialen KrankenversicherungWahrheit und Mythos [in:] Finanzierungsprobleme der gesetzlichen Krankenversicherung, ed. W.J. Pfeil, Vienna 2006, p. 9.
} 
of the contribution base. The BSVG sets a minimum contribution base of 850.07 euros for health and accident insurance, and 460.66 euros for pension insurance, regardless of the farm's actual profits. This amounts to taxation values of 4,000 euros for the health insurance and 2,200 euros for the pension insurance ${ }^{37}$. For the farm operator, the maximum contribution basis is 6,265 euros $^{38}$. In cases where spouses operate a farm together, the minimum contribution base is split between the two.

\section{Benefits}

Social insurance benefits in Austria are divided into those required by law and those established by the social insurance institutions' statutes ${ }^{39}$, meaning that they are enforceable through right of appeal by the insured or optional, non-enforceable, non-cash and cash benefits. Benefits in the event of illness include medical treatment by doctors, pharmaceuticals, medical aids (e.g. glasses) and medical devices (e.g. artificial limbs) and inpatient care ${ }^{40}$. The benefits and services of the health insurance system are largely provided as in-kind benefits. When it comes to doctors and dentists, these services should be provided predominantly through establishments owned by the social insurance institution (e.g. outpatient clinics) ${ }^{41}$ or through contracted facilities (hospitals) and contracted doctors. If a patient chooses treatment by a private doctor instead of one contracted by the SVS, a part of the costs is reimbursed. Instead of presenting an electronic insurance card and not paying upfront, the patient must pay the whole cost of the provided treatment. Following an application from the insured, 80 per cent of the amount that the SVS would have incurred for the same service by a contracted doctor are reimbursed ${ }^{42}$. As a major

37. This means that even if the taxation base is lower than the minimum contribution base, farmers still have to pay these amounts.

38. Austria's agriculture contains mostly small-structured farms. Around $50 \%$ of all farms have a taxation base of up to 10,000 euros, and approximately $8 \%$ only pay the minimum contribution, Statistik Austria, Land- und Forstwirtschaft, https://www.statistik.at/web_de/statistiken/wirtschaft/land_und_forstwirtschaft/index.html, access 26.03.2020.

39. As a result of the particular legal features of the social insurance system, the institutions may regulate some areas themselves by adopting internal rules, also called their statutes, and "sick person regulations". In these binding documents, the rights and obligations of insured persons are specified. Federal laws only determine the framework of these internal sources of law, while specifics are laid out in the statutes, e.g. the specific benefits. As these statutes and regulations are binding for each institution and the insured, insured persons may invoke their rights under the statutes in court.

40. SVB, Die bäuerliche Sozialversicherung im Überblick, Vienna 2019, p. $41 f$.

41. The SVB has owned five rehabilitation centres throughout Austria, also called its "own" establishments. These were specified to special health problems.

42. W. Hoffmann, Das Geldleistungssystem nach dem Bauernsozialversicherungsgesetz, "Soziale Sicherheit" 1994, p. 553. 
difference compared to general insurance ${ }^{43}$, farmers must pay a fixed contribution towards treatment costs in most cases ${ }^{44}$. Prior to 2020, the SVB did not have its own general contract and regulation on treatment fees with the Chamber of Medicine, but applied the provisions negotiated and laid down by one of the nine Regional Public Health Insurance Institutions, being independent and different social insurance institutions responsible for the social insurance of manual workers and employees depending on the location of the contracted health care provider ${ }^{45}$. The SVS, on the other hand, has negotiated a general contract with the Chamber of Medicine for all clients prior to the reform ${ }^{46}$. All contracted health professionals, regardless of whether they had a contract with the SVB or were covered by social insurance for the self-employed previously, have a contract with the SVS now.

When health insurance was first introduced for farmers, all medical services provided by doctors had to be paid in cash up front. This changed, after lengthy debate and negotiations, on 1 July 1998 when a legal reform established that farmers and their family members could be treated after presenting a voucher from the SVB. This meant that farmers no longer had to pay for costly treatments up front and would only have to pay their share of the costs afterwards. The electronic health insurance card or e-card, was introduced throughout Austria in 2005, replacing these vouchers. In 2008, a social law amendment introduced a ceiling on prescription fees for medication that was also applicable to farmers: after having paid two per cent of their annual net income for prescription fees, people are exempted automatically from further prescription fees for the remainder of the year in which the ceiling has been reached. Farmers' share of expenses for medical aids and medical devices was adjusted in 2009 to the ASVG level of $10 \%$ of the respective costs paid for by the insured person for the devices. The SVS grants farmers contributions towards the cost of employing temporary workers to support them during periods of incapacity to work. The benefits connected with pregnancy and motherhood are a maternity allowance, work assistance labourers replacing the mother's manpower and a childcare allowance ${ }^{47}$.

\footnotetext{
43. Ibidem.

44. $\$ 80$ Bauern-Sozialversicherungsgesetz (BSVG).

45. Since the reform of the social insurance institution system, the nine Regional Social Insurance Institutions were merged into one social insurance institution, responsible throughout Austria, the Österreichische Gesundheitskasse.

46. $\$ 51$ SVSG; K. Nakhai, S. Bunda, SVS: Gesamtvertrag mit der Ärztekammer besiegelt, https://www. ots.at/presseaussendung/OTS_20191119_OTS0107/svs-gesamtvertrag-mit-der-aerztekammer-besiegelt, access 30.03.2020.

47. SVB, Die bäuerliche Sozialversicherung im Überblick, Wien 2019, p. 44f. Both maternity allowance and childcare allowance are paid with federal money.
} 
Insured events covered under accident insurance are work-related accidents and occupational diseases. Benefits under accident insurance are more comprehensive than those under health insurance: accident treatment (apart from medical care this also includes medicines, therapeutic aids and nursing care in hospitals and sanatoriums) without cost sharing rules for the insured, partial reimbursement of the costs for replacement workers, occupational and social rehabilitation, and specific cash benefits $^{48}$. Farmers are entitled to receive assistance in the form of replacement workers if the farm operator or their relatives working full-time at the farm cannot work after a work-related accident, where the existing workforce is insufficient and there is work to be done that cannot be postponed. These workers should replace the lack of manpower in the daily work due to the accident. The general requirements for receiving such aid are: inpatient stays for over two days, inability to work for longer than 15 days, rehabilitation stays, death of a person eligible for benefits, accompanying a critically ill (disabled) child to a hospital or disabilities hindering further work on the farm. So-called "social" help is granted for a maximum of six months and has to be applied for. The SVS pays out according to the hourly rates of 9.50 euros per hour for a maximum of eight hours per working day. No more than $80 \%$ of the actual costs are reimbursed. After the first 90 working days, only six hours are paid for per working day ${ }^{49}$.

As medical treatments can be covered under either health insurance or accident insurance, the law provides the principle of pre-performance obligation (in German: Vorleistungspflicht) of the health insurance, so that the health insurance has to pay for any costs connected with necessary benefits or treatments and may later request the accident insurance to refund the cost $s^{50}$. Accident insurance for farmers covers entire farms, with one contribution per farm. The SVS offers safety-consulting services for the prevention of occupational disease at farms ${ }^{51}$.

The Austrian farmers' pension scheme covers different kinds of pensions depending on the insured event, namely age, the degree of reduced capacity to work and in the case of a farmer's death. In addition to pensions, famers receive additional benefits for every minor child ${ }^{52}$. There is the possibility for farmers to share their net pension with their spouse if the latter is not entitled to a pension of their $\mathrm{own}^{53}$. If

\footnotetext{
48. SVB, Die bäuerliche Sozialversicherung im Überblick, Vienna 2019, p. 54f.

49. SVS, Unfallversicherung im Überblick, https://www.svs.at/cdscontent/load?contentid=10008.729672\&version=1576763257 2020, p. 44, access 24.09.2020.

50. $\$ 148 \mathrm{r}$ Bauern-Sozialversicherungsgesetz (BSVG); F. Riedl, Die bäuerliche Unfallversicherung, Vienna 1998, p. 123.

51. F. Riedl, Die bäuerliche Unfallversicherung, Wien 1998, p. 57.

52. SVB, Die bäuerliche Sozialversicherung im Überblick, Vienna 2019, p. 69.

53. SVB, Die bäuerliche Sozialversicherung im Überblick, Vienna 2019, p. 72.
} 
both spouses operate a farm together, both spouses can acquire insurance periods within the pension insurance resulting in having their own entitlement to pension based on the insurance period each gained.

\section{SVS organisation and structure}

Austria's insurance institutions are regulated by national laws but execute their duties under the principle of self-government ${ }^{54}$. Until 31 December 2019, the former administrative bodies of the SVB were: the General Assembly, the Board, the Control Council (in German: Kontrollversammlung) and the Regional Committees for Benefits $^{55}$. After the structural reform this year, the administration was taken over by the General Meeting (in German: Hauptversammlung), the Administrative Board and the Committees of the Regional Offices ${ }^{56}$. The General assembly of the SVB was made up of either active farmers or members of the Chamber of Agriculture functioning as representatives (in German: Versicherungsvertreter) ${ }^{57}$. In order to become a representative, candidates, who were all full-time farmers, were voted indirectly as all farmers throughout Austria elected their stakeholders directly into the Chamber of Agriculture and the Chamber of Agriculture elected the representatives. The Chamber then sent their representatives to the administrative bodies of the $\mathrm{SVB}^{58}$. The chairwoman and her two proxies were elected from among the members of the Board, heading and representing the SVB in all external and legal relations ${ }^{59}$.

From its establishment up until 2001, the SVB had a decentralised structure. Following its reorganisation and restructuring, up until 31 December 2019, the SVB was a centrally organised institution with its head office in Vienna, together with the regional offices for Vienna and Lower Austria, and seven subsidiary regional offices. The regional offices had their own management but were bound to decisions and directives from the head office, which had final authority. Due to reasons of administrative simplification and skill bundling, competence centres with special responsibilities were established in the various regional offices (e.g. CC Nova for master data administration $)^{60}$. The SVS is also centrally organised, but its regional offices have

54. See J. Souhrada, Soziale Selbstverwaltung [in:] Selbstverwaltung in Österreich, ed. ÖVG, p. 191f.

55. $₫ 184$ Bauern-Sozialversicherungsgesetz (BSVG).

56. $₫ 16$ Selbständigen-Sozialversicherungsgesetz (SVSG).

57. SVB, Jahresbericht 2018, Vienna 2019, p. 140.

58. $₫ 185$ Bauern-Sozialversicherungsgesetz (BSVG).

59. SVB, Leitfaden der bäuerlichen Sozialversicherung 2019, Vienna 2019, p. 33.

60. SVB, Die bäuerliche Sozialversicherung im Überblick, Vienna 2019, p. 17. 
more decision-making authority ${ }^{61}$. The Minister for Health and the Minister for Finance have the right to oversee the SVS like all other social insurance institutions.

\section{Financial situation}

Individual benefits are financed through a pay-as-you-go system. The social pension scheme is based on the system that the compensations of the working generation and next generation of pensioners finance the pensions and benefits of the former generation of farmers while collecting time periods for the entitlement to receive a pension themselves when reaching a certain age limit and having worked for the necessary time laid out by the $\mathrm{law}^{62}$. This means that the contributions to the pension insurance are not saved and invested for the working generation but directly paid out to pensioners with the intention of future insurers paying for the benefits of the currently working generation. There are different statutory retirement ages in Austria; the determining factors in terms of whether an individual may apply for retirement pension benefits are retirement age and obtaining the required number of insurance periods ("insurance times/insurance months") ${ }^{63}$. The standard retirement age is 65 (for women born before 1 June 1968, there is a gradual increase from 60 to 65 wihin the following years depending on when these women, as having a different retirement age depending on the gender, was considered being discriminating $)^{64}$. The different schemes available in terms of early retirement are the corridor pension and the heavy labour pension; both entitle people to retirement benefits before reaching the normal retirement age. The additional requirement for retirement benefits is gaining a minimum amount of "insurance months". Either, someone has gained 180 insurance months, of which at least 84 must have been through an occupation, or they have gained 180 months in total within the past 360 months. Insurance months are not only counted as time while exercising an occupation but also time spent taking care of infants or in military service ${ }^{65}$.

A "corridor pension" may be applied for at the age of 62 if at least 40 insurance years (480 insurance months) have been completed ${ }^{66}$. If an individual has been engaged for at least ten of the previous twenty years in what can be classified as "heavy

61. $\$ 15$ Selbständigen-Sozialversicherungsgesetz (SVSG).

62. SVB, Die bäuerliche Sozialversicherung im Überblick, Wien 2019, p. 14.

63. $\$ 3$ Allgemeines Pensionsgesetz (APG).

64. $\$ \$ 102 \mathrm{ff}$ Bauern-Sozialversicherungsgesetz (BSVG).

65. $\$ \$ 107 \mathrm{a}-107 \mathrm{c}$ Bauern-Sozialversicherungsgesetz (BSVG); $\$ 4$ Sect. 5 Allgemeines Pensionsgesetz (APG).

66. $\$ 4$ Sect. 2 No. 1 and 2 Allgemeines Pensionsgesetz (APG). 
work" and a minimum of 45 insurance years have been completed by the age of 60 , that person is entitled to receive "heavy work" retirement benefits ${ }^{67}$. The amount of money they receive depends on the number of insurance months accrued and their past salaries throughout the years ${ }^{68}$. The main problem faced by this system is that even today one active contributor must pay for more than one pensioner. This has led to the SVB having one of the most unfavourable structures for insured persons among the insurance institutions in Austria ${ }^{69}$.

As mentioned before, the current contributions are not being invested in the financial money, but the social insurance is built on the principle of risk distribution between the old and the young, the healthy and the sick, richer and poorer ${ }^{70}$. Since the beginning of its existence, insurance for farmers could not cope with the financial burden without subsidies from the state. This resulted in the state having to co-finance health, pension and accident insurance ${ }^{71}$. Nowadays, federal contributions that co-finance pension insurance for farmers include so-called partner benefits and a liability guarantee ${ }^{72}$. Since farmers must pay contributions in their entirety on their own without being able to split them with their employer, the federal state contributes $5.8 \%$ of the contribution base from tax revenues of farms ${ }^{73}$. Beyond this amount, the federal state remits the difference between pensions insurance revenues and expenditures annually ${ }^{74}$. In addition to farmers' contributions, property owners from agricultural lands or lands used for forestry must contribute an additional amount of in land tax in order to finance farmers' accident insurance capital ${ }^{75}$. Tax authorities levy these additional costs and disburse them to the SVS.

The SVB's estimated expenditure in 2019 were 3.416 million euros. Of the total expenses, health insurance accounted for $18.3 \%$, accident insurance $-3.4 \%$, pension

67. $\$ 108$ a Bauern-Sozialversicherungsgesetz (BSVG); $\$ 4$ Sect. 3 Nr. 1 and 2 Allgemeines Pensionsgesetz (APG).

68. $₫ 5$ Allgemeines Pensionsgesetz (APG).

69. Dachverband der Sozialversicherungsträger, Statistische Daten aus der Sozialversicherung - Versicherte, Pensionen, Renten - Jahresergebnisse 2019, Tabelle 11, https://www.sozialversicherung.at/cdscontent/load? contentid=10008.731875\&version=1580747874, access 30.03.2020; E. Bruckmüller, R. Sandgruber, H. Stekl, Soziale Sicherheit im Nachziehverfahren - Die Einbeziehung der Bauern, Landarbeiter, Gewerbetreibenden und Hausgehilfen in das System der österreichischen Sozialversicherung, Salzburg 1978, p. 109.

70. SVB, Leitfaden der bäuerlichen Sozialversicherung 2019, Vienna 2019, p. 26.

71. G. Schwarz, Das bäuerliche Sozialsystem. Die Sozialversicherungsanstalt der Bauern im 30. Jahr ihres Bestehens, "Ländlicher Raum" 2004, Nr. 5, p. 5.

72. HVB, Handbuch der österreichischen Sozialversicherung 2018, April 2018, p. 86. Compare M. Sonntag, Zur Zulässigkeit der Ausfallhaftung des Bundes für die gesetzliche Pensionsversicherung aus verfassungsrechtlicher Sicht, “ Journal für Rechtspolitik” 2017, p. 85.

73. $\$ 24$ Bauern-Sozialversicherungsgesetz (BSVG). This percentage is the difference between the amount famers have to pay into their pension scheme and the standardised contribution rate concerning pension insurance of $22.8 \%$.

74. $₫ 31$ Bauern-Sozialversicherungsgesetz (BSVG).

75. $₫ 30$ Bauern-Sozialversicherungsgesetz (BSVG). 
insurance $-71.7 \%$, and care allowance $-6.6 \%^{76}$. While the federal state financed approximately 2409 million euro (being 70.5\%) of SVB's expenditure, the contributions of insured parties made up $29.5 \%{ }^{77}$.

\section{Tasks of the SVS}

As stated above, social insurance in Austria is composed of health, pension and accident insurance. When a person is insured under all three types, they are said to have full insurance; otherwise, they are said to have partial insurance. Within the agricultural sector, the SVS covers health, accident and pension insurance, in accordance with the BSVG ${ }^{78}$. In addition to the obligatory benefits provided for by federal laws, the SVS offers voluntary benefits to farmers. It is also responsible for the distribution of care allowances and maternity allowances to eligible farmers and their relatives.

The tasks of the SVS in the matters of the health insurance laid down by the law are health promotion ${ }^{79}$, early recognition and prevention of diseases, benefits in the event of illness or pregnancy, support for physical infirmities and support in the event of incapacity to work due to disease ${ }^{80}$.

To ensure the flow of information, the SVB published a newspaper for all farmers quarterly, reporting on new legal changes and other relevant information for farmers and their families. The newspaper was sent to each insured person automatically ${ }^{81}$. Another way of informing insured people was through "LIVE", an annual personalised information notification about all benefits and treatments received by an individual under health insurance.

76. Long-term care benefits are divided into seven stages depending on the hours per month of care required. The allowance is intended to cover care-related costs only and does not provide an increase in income. The care allowance is paid out under pension insurance but financed with federal money.

77. SVB, Die bäuerliche Sozialversicherung im Überblick, Vienna 2019, p. 13.

78. $\$ 1$ Bauern-Sozialversicherungsgesetz (BSVG). The Agricultural Worker Act (Landarbeitsgesetz) defines what is categorised as agricultural productions.

79. F. Riedl, Die bäuerliche Unfallversicherung, Vienna 1998, p. 57.

80. SVB, Die bäuerliche Sozialversicherung im Überblick, Vienna 2019, p. 39.

81. SVB, Leitfaden der bäuerlichen Sozialversicherung 2019, Vienna 2019, p. 38f. 


\section{Rehabilitation}

Rehabilitation measures are available either under accident insurance or under pension insurance ${ }^{82}$. If rehabilitation is necessary after a work-related accident or due to an occupational disease, and only in these two cases, accident insurance covers rehabilitation for the purpose of restoring the ability to work on a farm or in a different occupation ${ }^{83}$. The insured person must consent to any rehabilitation measures in advance and cannot be forced by the institution ${ }^{84}$. In order to decide on effective measures, a rehabilitation plan is arranged with the insured. This plan also includes the rehabilitation goals aimed for during the treatment and the planned measures ${ }^{85}$. Health insurance coverage includes medical interventions in connection with rehabilitation to ensure the success of a medical treatment or to relieve the consequences of an illness. Available measures include inpatient stays at specialised rehabilitation centres, prostheses and other medical or therapeutic aids, medical treatment, medicines, subsidies for farmhands and partial transport costs ${ }^{86}$. During the rehabilitation process, farmers receive rehabilitation money, which is disbursed fourteen times a year ${ }^{87}$.

The last available form of retirement for farmers, apart from the regular retirement, corridor pension and heavy work pension mentioned above, which is relevant in the context of rehabilitation, is a vocational disability pension. A farmer is regarded as being incapable of working (in general) if they cannot pursue any regular profession, either employed or self-employed, for health reasons. After the age of 60 , a farmer is regarded as being incapable of working if they cannot pursue the profession they practiced for the 120 of the preceding 180 calendar months ${ }^{88}$. In the latter case, the time spent active as a farmer and the feasibility of working as a farmer again are of relevance, while before the age of 60 , the capability of being able to work in any sector is examined. Following the principle of rehabilitation before pension, an application for benefits on these grounds is firstly regarded as applying for (medical) rehabilitation services. Pension insurance pays for rehabilitation if there is a high probability the available measures will be able to reduce or prevent the farmer's inability to work. Only in cases where vocational rehabilitation is not practicable or

82. $\$ 122$ Bauern-Sozialversicherungsgesetz (BSVG).

83. $\$ 148$ y Bauern-Sozialversicherungsgesetz (BSVG); F. Riedl, Die bäuerliche Unfallversicherung, Vienna 1998 , p. 132 f.

84. $\$ 149 \mathrm{c}$ Bauern-Sozialversicherungsgesetz (BSVG).

85. F. Riedl, Die bäuerliche Unfallversicherung, Vienna 1998, p. 138.

86. SVB, Leitfaden der bäuerlichen Sozialversicherung 2019, Wien 2019, p. 147.

87. $\$ 148 \mathrm{~g}$ Bauern-Sozialversicherungsgesetz (BSVG).

88. $₫ \$ 124 \mathrm{ff}$. Bauern-Sozialversicherungsgesetz (BSVG). 
reasonable, or no improvement in the ability to work is foreseeable are farmers entitled to a vocational invalidity pension ${ }^{89}$.

The SVB owned five rehabilitation institutions throughout Austria, each one specialised in a different medical field. After the structural reform and financial troubles that began in $2004^{90}$, the SVB's management decided to partially privatise these institutions and kept only $26 \%$ of the shares ${ }^{91}$. In 2010 all institutions owned by the SVB were partially privatised.

In addition to rehabilitation treatment, there is the option for injured persons to be allocated a rehabilitation advisor from the institution to support them in times of sickness by making sure they get the necessary financial support as well as medical and therapeutic aids. The advisor also organises timely follow-up treatments, if possible, in one of the institution's own rehabilitation institutions mentioned above ${ }^{92}$.

\section{Prevention}

The importance of preventive medicine has always been a central aspect of farmers' insurance and has become more important over the years. Various approaches to the topic and communicating important messages the farmers and farms were found. Yearly financial contributions for dental hygiene for family members and co-insured minors have been applied as a preventive measure for improving dental health since $2013^{93}$. In 1973, the SVB started to invite adolescents between the ages of 15 and 18 with agricultural backgrounds for annual preventive check-ups ${ }^{94}$. The SVS has continued this service.

So-called SVB-Gesundheitsaktionen, health campaigns tailored to the needs and health issues of farmers and their family members employed full-time on their farms were launched, evaluated annually and expanded. Within these programmes and options for insured parties, special programmes for children and adolescents

89. $\$ 123$ Bauern-Sozialversicherungsgesetz (BSVG). Pension insurance in Austria operates under the slogan "rehabilitation before pension"; PVA, Berufliche Rehabilitation, https://www.pensionsversicherung.at/cdscontent/? contentid=10007.707590\&portal=pvaportal, access 27.03.2020.

90. After a 2004 ruling of the Austrian Constitutional Court, the SVB was excluded from the National Compensation Fund for the social insurance institutions with immediate effect. This meant that the institution had to cope with its debts suddenly on its own; VfGH G 279-02, 13.03.2004; Another factor contributing to the high debts was the significant decrease of farmers with fewer active contributing payers and the parallel increase in health care costs.

91. G. Schwarz, 50 Jahre Krankenversicherung für Bäuerinnen und Bauern, "Soziale Sicherheit" 2016, p. 29.

92. Ibidem, p. $30 \mathrm{f}$.

93. SVB-Generalversammlung vom 19. November 2013, "Soziale Sicherheit" 2013, p. 565.

94. SVB, 40 Jahre Alles aus einer Hand seit 1974, Vienna 2014, p. 26. 
as future farmers are offered. Particular emphasis is placed on nutrition, exercise, smoking, alcohol consumption and noise exposure with the hope that the learned skills will be considered by these young people if and when they eventually become farm operators and owners. Insured persons can obtain advice and information on preventive measures and the range of health campaigns available online and in person at the regional offices ${ }^{95}$. For retired or elderly farmers, special lectures and health days are held by the SVS. The discussed topics include healthy lifestyles and age-appropriate living, fall prevention and information on non-communicable diseases ${ }^{96}$. Other information campaigns connected to medical preventive measures are focussed on healthy blood pressure, quitting smoking and information on the sun and UV radiation ${ }^{97}$.

The insurance institution sends advisors and safety experts upon request to individual farms to offer guidance onsite on how to prevent work-related accidents and diseases ${ }^{98}$. As an additional promotion of safe work environments on farms, famers may receive safety awards after implementing recommendations and achieving compliance with safety standards. These awards are presented and distributed publicly. SVS experts hold lectures on safe working methods at agricultural schools and universities. Furthermore, the SVS finances road safety training, first aid courses and protective equipment ${ }^{99}$.

One of the cornerstones of preventive efforts was the introduction of a free TBE vaccination for farmers: All insured parties and their relatives are entitled to get a free TBE shot according to the SVB's nationwide vaccination programme as preventive action against tick-borne encephalitis. Once a farmer has been registered within the programme, an automated reminder and invitation to the next possible appointment is sent in the year the next vaccination is necessary. If a farmer gets vaccinated independently by a physician, reimbursement of the doctor's fee is provided in the amount of 17.09 euros $^{100}$.

95. G. Schwarz, 50 Jahre Krankenversicherung für Bäuerinnen und Bauern, "Soziale Sicherheit" 2016, p. 30f. 96. Lebensstil verbessern, https://www.svs.at/cdscontent/? contentid=10007.854105\&portal=svsportal, access 4.04.2020.

97. SVB, Leitfaden der bäuerlichen Sozialversicherung 2019, Vienna 2019, p. $116 f$.

98. SVB-Generalversammlung vom 19. November 2013, "Soziale Sicherheit" 2013, p. 565.

99. ENASP, Tailor-Made Services for Rural Populations, 2019, p. 22.

100. SVB, Leitfaden der bäuerlichen Sozialversicherung 2019, Vienna 2019, p. 110; FSME-Impfaktion für Bauern, https://www.svs.at/cdscontent/? contentid=10007.835090, access 28.03.2020. 


\section{Health actions/programmes}

The SVS offers various specialised health initiatives and programmes to insured farmers and their relatives dealing with different life situations or medical conditions while being away from home and the farms. Since 2001, the SVB has offered health initiatives for children insured under the BSVG. Around 400 children participate every summer. For children between eight and fifteen years of age, the SVS offers programmes focusing on weight problems, skin diseases, dyslexia, orthopaedic problems, and pulmonary diseases. These programmes were extended to children and adolescents in particularly stressful situations and the promotion of healthy lifestyles in 2017. During their stay, participants receive professional therapeutic support to learn to better manage and overcome burdensome experiences in life, such as the loss of a relative or serious illnesses. This support focuses on not only physical activities and health lectures but also other activities like reading for the duration of 17 days $^{101}$.

The SVB created the Fit4Life support programme for pupils with agricultural backgrounds. Under the programme, health experts hold lectures on information days and support schools and families in creating healthy school environments, and raising awareness of proper nutrition and exercise for children. Experts also talk about dangers posed to children on farms and give recommendations on how to prevent accidents ${ }^{102}$. Another programme for families with younger children involves a 17-day stay in Lignano, Italy, for children suffering from skin or respiratory diseases. The "young family" health initiative is tailored to the special needs of overburdened mothers. While staying with at least one child up to six years of age at a hotel, mothers are able to learn from professionals from psychosocial backgrounds about how to deal with acutely stressful situations. These breaks from working on farms offer young mothers the opportunity to relax both physically and psychologically ${ }^{103}$. Three months after the stay, a three-day follow-up is offered to participants with the goal of achieving maximum sustainability of the newly learned skills ${ }^{104}$.

Special lectures and short stays aimed at raising awareness and helping with burnout prevention, stress reduction techniques and combatting the taboo surrounding

101. SVB, Leitfaden der bäuerlichen Sozialversicherung 2019, Vienna 2019, p. 112.

102. ENASP, Tailor-Made Services for Rural Population, 2019, p. 5; SVB, Leitfaden der bäuerlichen Sozialversicherung 2019, Vienna 2019, p. 240.

103. SVB, 40 Jahre Alles aus einer Hand seit 1974, Vienna 2014, p. 53.

104. ENASP, Tailor-Made Services for Rural Population, 2019, p. 20; SVB, Leitfaden der bäuerlichen Sozialversicherung 2019, Wien 2019, p. 242. 
mental health disorders are offered to farmers. Elderly farmers prone to burnout or fatigue can take part in a three-week health initiative offering them psychosocial support, the opportunity to relax and focus on improving their mental and physical wellbeing. Since the first programme started in 2006, 2,699 farmers have participated.

Depending on their needs, the SVB started to offer rehabilitation and spa treatments for retired participants on a three- or four-week stay at a health resort. In cases of psychological problems, up to six-week-long programmes in specialised rehabilitation facilities are offered ${ }^{105}$.

Three different health initiatives are available for caregiving relatives looking after a care receiver who is cared for at home and entitled to a nursing allowance since 1998. While 15-day stays available to caregiving relatives are focused on relaxation and rest, a specialised initiative is available for parents looking after disabled children ${ }^{106}$. After the passing of a care-receiving insured person, starting in 2013, relatives who provided nursing care for a certain amount of time before the death are able to participate in a 15-day stay within one year of their relative's death, helping them to reset and process their grief ${ }^{107}$.

The health initiative related to "women/men in special circumstances" has offered active farmers a 15-day break from work with the goal of offering assistance in personal crisis management and reducing psychological burdens through professional support since 1991. In addition to improving mental well-being, there is an emphasis on the physical health of the participants as well. These special circumstances include illnesses, death of a partner or family member, divorce and professional burnout. Approximately 90 women and 30 men can participate in these programmes after coming to a consultation meeting beforehand. Within one year, participants are asked to come to two three-day follow-up meetings, where amongst other things, the implementation of the learned skills in participants' daily lives is discussed $^{108}$.

In order to facilitate the process of transferring a farm to the next generation and retiring, an initiative designed to facilitate this transfer was initiated. Other topics of these stays were healthy ageing and stress-reduction methods ${ }^{109}$. Lastly, farmers staying at a farm categorised as a "green-care farm" for vacation are entitled to

105. ENASP, Tailor-Made Services for Rural Population, 2019, p. 10.

106. SVB, Leitfaden der bäuerlichen Sozialversicherung 2019, Vienna 2019, p. $243 f$.

107. SVB, Leitfaden der bäuerlichen Sozialversicherung 2019, Vienna 2019, p. 245.

108. SVB, Leitfaden der bäuerlichen Sozialversicherung 2019, Vienna 2019, p. 247.

109. SVB, Leitfaden der bäuerlichen Sozialversicherung 2019, Vienna 2019, p. 246. 
receive 100 "green-care" Euro from the SVS as a small copayment to the expenses of a holiday ${ }^{110}$.

In cooperation with the other health insurance institutions, the SVB has started a special network and programme for people dealing with dementia and their relatives in Lower Austria ${ }^{111}$. Other projects the SVB has started with other key players under the leadership of the former Styrian Social Insurance Institution is a disease management programme for diabetes patients ${ }^{112}$. Patients registered in the programme go to regular check-ups with registered DMP-doctors. The latter document important parameters at these regular appointments and consultations on diabetes and related health problems. The goal of this programme is to enhance quality of life and prolong life expectancy. After just two years, participants showed positive results and their wellbeing had improved ${ }^{113}$. The SVS now continues these actions and programmes.

\section{International cooperation}

The Sozialversicherung der Selbständigen (SVS) is, as was its processor - the Sozialversicherungsanstalt der Bauern (SVB), a member of several international organisations. In 2015, the SVB became a member of the Association Internationale de la Mutualité (AIM) and a member of European Network of Agricultural Protection Systems (ENASP) in 2005.

\section{Bibliography}

Aubauer H., Rosenmayr-Khoshideh M., Sozialversicherungs-Organisationsreform und Grenzen der Staatsaufsicht, "Zeitschrift für Arbeitsrecht und Sozialrecht" 2019, Nr. 11.

Berghold A., Nagy H., Disease-Management-Programme “Therapie Aktiv - Diabetes im Griff”, "Soziale Sicherheit" 2015.

110. Green Care Österreich, SVB und Green Care Österreich kooperieren zum Wohle der bäuerlichen Gesundheit, 1.02.2018, https://www.greencare-oe.at/svb-und-green-care-oesterreich-kooperieren-zum-wohle-der-baeuerlichen-gesundheit+2500+2441844, access 29.03.2020.

111. Das Demenz-Service NÖ, https://www.demenzservicenoe.at/, access 23.03.2020.

112. A. Berghold, H. Nagy, Disease-Management-Programme "Therapie Aktiv - Diabetes im Griff”, "Soziale Sicherheit" 2015, p. 417; CCIV, Disease Management Programme Diabetes mellitus Typ 2 "Therapie Aktiv", https://www.cciv.at/cdscontent/? contentid=10007.678462\&viewmode=content, access 24.03.2020.

113. H. Nagy, Disease Management in Österreich - Patientinnen und Patienten profitieren vom DMP, https://www.sozialversicherung.at/cdscontent/?contentid=10007.844540\&portal=svportal, access 16.04.2020. 


\section{Social Insurance for farmers in Austria - from its inception to the SVS}

Bruckmüller E., Sandgruber R., Stekl H., Soziale Sicherheit im Nachziehverfahren - Die Einbeziehung der Bauern, Landarbeiter, Gewerbetreibenden und Hausgehilfen in das System der österreichischen Sozialversicherung, Salzburg 1978.

CCIV, Disease Management Programme Diabetes mellitus Typ 2 “Therapie Aktiv”, https://www.cciv.at/ cdscontent $/$ ? contentid=10007.678462\&viewmode=content, access, 24.03.2020.

Dachverband der Sozialversicherungsträger, Statistische Daten aus der Sozialversicherung - Versicherte, Pensionen, Renten - Jahresergebnisse 2019, Tabelle 11, https://www.sozialversicherung.at/cdscontent/ load? contentid=10008.731875\&version=1580747874, access 30.03.2020.

Das Demenz-Service NÖ, https://www.demenzservicenoe.at/, access 23.03.2020.

Die Sozialversicherung bietet Schutz für 8,8 Millionen Menschen, “Soziale Sicherheit” 2019.

ENASP, Tailor-Made Services for Rural Populations, 2019.

Green Care Österreich, SVB und Green Care Österreich kooperieren zum Wohle der bäuerlichen Gesundheit, 01.02.2018, https://www.greencare-oe.at/svb-und-green-care-oesterreich-kooperieren-zum-wohle-der-baeuerlichen-gesundheit+2500+2441844, access 29.03.2020.

Hoffmann W., Das Geldleistungssystem nach dem Bauernsozialversicherungsgesetz, "Soziale Sicherheit” 1994.

HVB, Handbuch der österreichischen Sozialversicherung 2018, April 2018.

Kandlhofer J., Eine Ursachenanalyse der Finanzierungsprobleme der sozialen Krankenversicherung - Wahrheit und Mythos [in:] Finanzierungsprobleme der gesetzlichen Krankenversicherung, ed. W.J. Pfeil, Vienna 2006.

Kranewitter H., Ausgedinge, “Österreichische Zeitschrift für Liegenschaftsbewertung” 2009, Nr. 36.

Lidauer H., Neuregelung der Zuordnung von Sozialversicherten nach dem SV-ZG, "Journal für Arbeitsrecht und Sozialrecht" 2018.

Nagy H., Disease Management in Österreich - Patientinnen und Patienten profitieren vom DMP, https:// www.sozialversicherung.at/cdscontent/? contentid=10007.844540\&portal=svportal, access 16.04.2020

Nakhai K., Bunda S., SVS: Gesamtvertrag mit der Ärztekammer besiegelt, https://www.ots.at/presseaussendung/OTS_20191119_OTS0107/svs-gesamtvertrag-mit-der-aerztekammer-besiegelt, access 30.03.2020.

PVA, Berufliche Rehabilitation, https://www.pensionsversicherung.at/cdscontent/?contentid=10007.707590 \&portal=pvaportal, access 27.03.2020.

Riedl F., Die bäuerliche Unfallversicherung, Vienna 1998.

Schwarz G., 50 Jahre Krankenversicherung für Bäuerinnen und Bauern, "Soziale Sicherheit” 2016.

Schwarz G., Das bäuerliche Sozialsystem. Die Sozialversicherungsanstalt der Bauern im 30. Jahr ihres Bestehens, "Ländlicher Raum” 2004, Nr. 5.

Soziale Sicherheit, SVB-Generalversammlung vom 19. November 2013, "Soziale Sicherheit" 2013.

Sonntag M., Zur Zulässigkeit der Ausfallhaftung des Bundes für die gesetzliche Pensionsversicherung aus verfassungsrechtlicher Sicht, "Journal für Rechtspolitik" 2017.

Souhrada J., Pflichtversicherung oder Versicherungspflicht in der Krankenversicherung, "Soziale Sicherheit" 2001.

Souhrada J., Soziale Selbstverwaltung [in:] ed. ÖVG, Selbstverwaltung in Österreich.

Statistik Austria, Land- und Forstwirtschaft, https://www.statistik.at/web_de/statistiken/wirtschaft/ land_und_forstwirtschaft/index.html, access 26.03.2020. 


\section{Social Insurance for farmers in Austria - from its inception to the SVS}

Steiner G., Siegl G., Ja, jetzt geht es mir gut... Entwicklung der bäuerlichen Sozialversicherung in Österreich, 2010. SVB, 40 Jahre Alles aus einer Hand seit 1974, Vienna 2014.

SVB, Die bäuerliche Sozialversicherung im Überblick, Vienna 2019.

SVB, Jahresbericht 2018, Vienna 2019.

SVB, Leitfaden der bäuerlichen Sozialversicherung 2019, Vienna 2019.

SVS, Bäuerliche Nebentätigkeiten I, Vienna January 2020, https://www.svs.at/cdscontent/load? contentid $=10008.732003 \&$ version $=1580914454$, access 24.09.2020.

SVS, FSME-Impfaktion für Bauern, https://www.svs.at/cdscontent/? contentid=10007.835090, access 28.03.2020.

SVS, Lebensstil verbessern, https://www.svs.at/cdscontent/? contentid=10007.854105\&portal=svsportal, access 4.04.2020.

SVS, Unfallversicherung im Überblick, https://www.svs.at/cdscontent/load?contentid=10008.729672 \&version=1576763257 2020, access 24.09.2020.

VfGH G 279-02, 13.03.2004.

This article is licensed under a Creative Commons Attribution 4.0

International license (CC BY 4.0) 